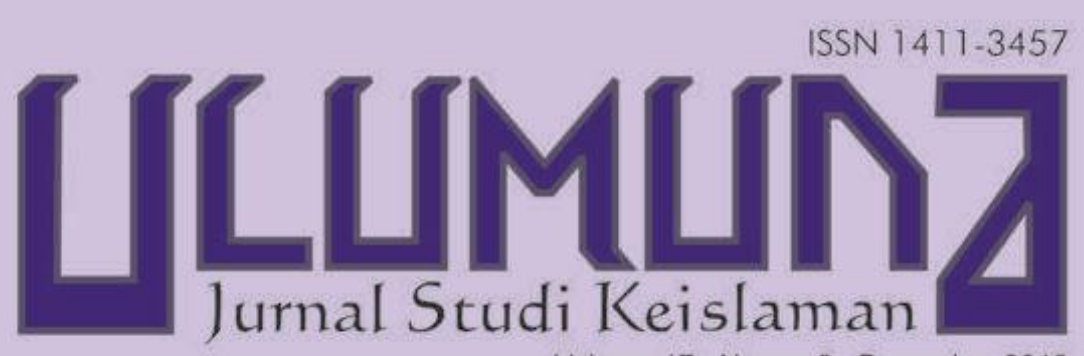

Volume 17· Nomor 2 - Desember 2013

TERAKREDITASI [3, SK Dirjen Dik: Kenmikind Nomor: 56 DIKTIKep 2012. Targgal 24 junt 2012

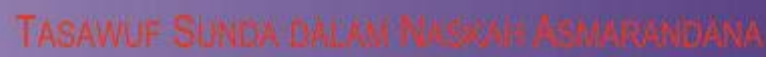
$767(6)$

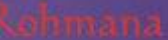

(s):

DALAM TRADISI KEAGM

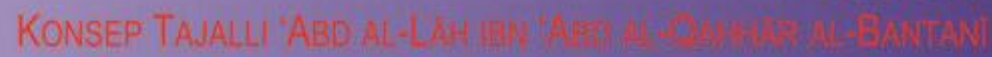

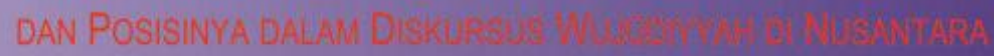

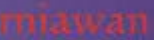

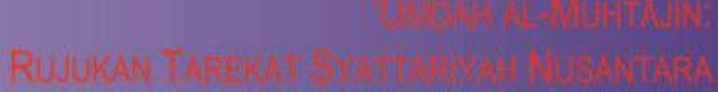

manherit

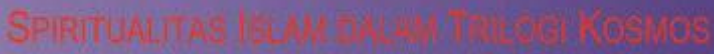

1) thits

YOWMAN:

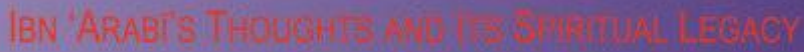

3ेputra

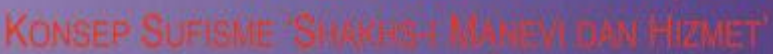

GUIEN

(umayi

Acoxuma

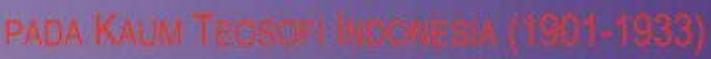

Babei

BASAWUF

Tanany

upinkat 



\section{DAFTAR ISI}

\section{Pedoman Transliterasi}

\section{1-258 • Jajang A Rohmana}

"Tasawuf Sunda dalam Naskah Asmarandana

Ngagurit Kaburu Burit (OR. 7876)”

259-274 • Mashadi

"Konteks dan Corak Mistisisme Islam

dalam Tradisi Keagamaan Masyarakat Gorontalo"

275-302 • Ade Fakih Kurniawan

"Konsep Tajalli 'Abd al-Lāh ibn 'Abd al-Qahhār

al-Bantanī dan Posisinya dalam Diskursus

Wujūdiyyah di Nusantara"

303-322 • Damanhuri

“Umdah al-Muhtàjīin:

Rujukan Tarekat Syattariyah Nusantara"

\section{3-346 • Munawir Haris}

"Spiritualitas Islam dalam Trilogi Kosmos"

347-358 - Hans Abdiel Harmakaputra

"Becoming a Perfect Human:

Ibn 'Arabî's Thoughts and Its Spiritual Legacy"

359-386 • Sulaiman Al-Kumayi

"Konsep Sufisme 'Shakhs-i Manevi dan Hizmet'

Muhammad Fethullah Gülen"

387-420 • Media Zainul Bahri

"Gagasan Pluralisme Agama

pada Kaum Teosofi Indonesia (1901-1933)"

421-440 • Lalu Supriadi

"Studi Komparatif Pemikiran Tasawuf

al-Ghazali dan Ibn Taimiyah"

\section{LAMPIRAN-LAMPIRAN}




\section{PEDOMAN TRANSLITERASI}

\begin{tabular}{|c|c|c|c|c|c|c|}
\hline 1 & $=$ & $\mathbf{a}$ & & $\dot{\varepsilon}$ & $=$ & $\mathrm{g}$ \\
\hline ب & $=$ & b & & ف & $=$ & f \\
\hline$ت$ & $=$ & $\mathbf{t}$ & & ق & $=$ & $q$ \\
\hline$\dot{H}$ & $=$ & th & & ك & $=$ & $\mathbf{k}$ \\
\hline ج & $=$ & $\mathbf{j}$ & & J & $=$ & 1 \\
\hline$\tau$ & $=$ & ḥ & & s & $=$ & $\mathrm{m}$ \\
\hline$\dot{\tau}$ & $=$ & $\mathbf{k h}$ & & $\dot{ن}$ & $=$ & $\mathbf{n}$ \\
\hline$د$ & $=$ & d & & 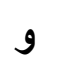 & $=$ & $\mathbf{w}$ \\
\hline$\dot{j}$ & $=$ & dh & & ○ & $=$ & $\mathbf{h}$ \\
\hline$\jmath$ & $=$ & $\mathbf{r}$ & & $\varepsilon$ & $=$ & , \\
\hline j & $=$ & $\mathbf{z}$ & & ي & $=$ & $\mathbf{y}$ \\
\hline س س & $=$ & s & & & & \\
\hline 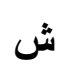 & $=$ & sh & \multicolumn{4}{|c|}{ Untuk Madd dan Diftong } \\
\hline ص - ص & $=$ & ș & i & $=$ & \multicolumn{2}{|c|}{$\bar{a}$ (a panjang) } \\
\hline ض ض & $=$ & d & إي & $=$ & \multicolumn{2}{|c|}{$\overline{1}$ (i panjang) } \\
\hline b & $=$ & $t$ & أو & $=$ & \multicolumn{2}{|c|}{ ù (u panjang) } \\
\hline ظ & $=$ & z & او & $=$ & \multicolumn{2}{|c|}{ aw } \\
\hline$\varepsilon$ & $=$ & ' & أي & $=$ & \multicolumn{2}{|l|}{ ay } \\
\hline
\end{tabular}

Contoh penulisan dengan transliterasi:

(a'üdhu bi al-Lāh min al-shaytān al-rajim); اعوذ بالله من الشيطان الرجيم

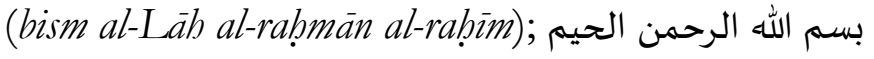

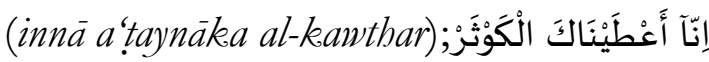

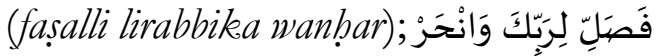

(șabāḥ al-khayr). صبباح الخير 


\title{
TASAWUF SUNDA DALAM NASKAH ASMARANDANA NGAGURIT KABURU BURIT (OR. 7876)
}

\author{
Jajang A Rohmana \\ (UIN Sunan Gunung Djati Bandung \\ Email: jajang_abata@yahoo.co.id)
}

Abstract: The spread of Islam in the Archipelago was closely tied to the roles of Sufi ulama. The circulation of Sufi work in Nusantara proves a strong connection between this region and the Middle East. In West Java, a number of these work expose Sufi teachings in the form of Sundanese Sufi literature, such as the work by Haji Hasan Mustafa. He is considered the greatest Sundanese poet whose work features strong influences of wahdat al-wujud. This paper aims to examine Sundanese Sufism expressed in Mustafa's work of Asmarandana Ngagurit Kaburu Burit. This study shows that this work contains Sufi's path that explores the self and its encounters with Supreme Being and the self's diffusion, where there is no longer existence except the One. Mustafa called his Sufi poetry imperfect suluk because it was written in late afternoon. His work reveals local Sufi accommodation to wahdat al-wujud in Sundanese language and culture.

Abstrak: Seiringan dengan perkembangan Islam di Nusantara adalab beredarmya naskah-naskah tasawuf membuktikan adanya bubungan kuat tradisi tasawuf lokal dan Timur Tengah. Di tatar Sunda, sejumlah naskah tasawuf mengekspresikan ajarannya ke dalam bentuk sastra sufistik Sunda (dangding, guguritan). Artikel ini bertujuan untuk mengkaji ekspresi pengalaman tasawuf Sunda dalam naskah Asmarandana Ngagurit Kaburu Burit (Cod. Or. 7876) karya Haji Hasan Mustapa (1852-1930), sufi sekaligus pujangga Sunda yang dipengarubi ajaran wabdah al-wujüd. Dalam naskah itu tergerai ungkapan perjalanan sufistik (susulukan) sang penulisnya. Bermula pada tahap pencarian diri saat hingga mengalami pertemuan (pasamoan, sapatemon). Puncaknya adalah pengalaman membaurnya eksistensi diri (fanā', pakula-kula) dalam kesejatian sempurna di alam jatnika. Karya Mustapa ini mencirikan kreativitas lokal dalam menyerap pengaruh tasawuf waḥdah al-wujud yang diekspresikean dengan bahasa sastra dan alam Sunda.

Keywords: tasawuf Sunda, naskah, pengalaman batin. 
PERKEMBANGAN Islam di Nusantara sejak semula diwarnai oleh ajaran dan praktek tasawuf. Ia merupakan salah satu faktor yang membuat Islamisasi di Nusantara menjadi sangat mungkin. ${ }^{1}$ Tasawuf mempermudah terjadinya resepsi Islam di Nusantara yang dipertemukan dengan alam kebatinan masyarakat setempat. $^{2}$ Beredarnya naskah tasawuf lokal Nusantara membuktikan perannya dalam proses Islamisasi sebagai tafsir atas tradisi tasawuf Timur Tengah. ${ }^{3}$

Di tatar Sunda, sejumlah naskah menunjukkan kreativitas sufistik ke dalam bentuk puisi lokal Sunda. Sastra sufistik Sunda seperti dangding, wawacan, atau guguritan merupakan salah satu media ekspresi sufistik yang terdapat dalam naskah Sunda abad XVIII-XIX. ${ }^{4}$ Dangding (metrical verses) kiranya dianggap efektif dalam mengungkapkan perasaan sufistik ke dalam bahasa sastra lokal sesuai dengan alam budayanya. Kreativitas sufistik lokal menjadi karakter unik yang membentuk wajah tasawuf di Nusantara.

Salah satu naskah dangding sufistik Sunda yang belum banyak dikaji adalah karya Haji Hasan Mustapa (1852-1930). Ia dianggap sebagai sufi sekaligus bujangga Sunda terbesar yang menuangkan pengalaman spiritualnya ke dalam dangding. Terdapat lebih dari 10.000 bait puisi dangding dalam hampir 100 judul puisi beraksara pegon. Semua dangding tasawuf tersebut ditulisnya dalam rentang waktu yang cukup singkat (1900-1902). Signifikansi karyanya itu tidak saja pada jumlahnya yang banyak itu, tetapi terletak pada artikulasi tasawuf lokal dalam mengungkapkan pengalaman batin tasawufnya. Ia menunjukkan interpretasi tasawuf dengan citarasa orang Sunda. ${ }^{5}$

${ }^{1}$ A.H. Johns, "Sufism as a Category in Indonesian Literature and History", Journal of Southeast Asian History, vol. 2, no. 2, 1961, 10-23; Martin van Bruinessen, "The Origins and development of Sufi orders (tarekat) in Southeast Asia, Studia Islamika, vol.1, no. 1, 1994, 3.

Julian Patrick Millie, "Splashed by the Saint: Ritual Reading and Islamic Sanctity in West Java", Disertasi (Leiden University, 2006), 193-4.

3Oman Fathurahman, Itäf al-Dhaki, Tafsir Wabdatul Wujud bagi Muslim Nusantara (Bandung: Mizan-EFEO, 2012), 44.

${ }^{4}$ Edi S. Ekadjati, Naskah Sunda: Inventarisasi dan Pencatatan (Bandung: Lembaga Penelitian Unpad-The Toyota Foundation, 1988).

5Jajang A Rohmana, "Sundanese Sufi Literature and Local Islamic 
Meski beberapa sarjana sudah melakukan kajian tentang Mustapa, namun naskah Asmarandana Ngagurit kiranya belum mendapatkan perhatian. Di samping akses yang cukup sulit karena hanya tersimpan di UB Leiden, kiranya bahasa dan aksaranya juga tidak mudah dibaca dan dipahami. Terlebih ia merupakan naskah tasawuf yang seringkali disalahpahami karena mengelaborasi pengalaman batin secara simbolis dan metaforis. Beberapa kajian seperti Abas, Jahroni, dan Gibson misalnya, cenderung melihat sisi pemikiran sufistiknya dalam berbagai karya Mustapa yang sudah dipublikasikan dihubungkan dengan genealogi tasawuf yang mempengaruhinya. ${ }^{6}$ Sementara Rosidi yang sejak 1960-an cukup intens menelusuri dan mempublikasikan karya-karya Mustapa, kiranya terbatas pada upaya merekonstruksi kepribadiannya dan kemudian menyajikan karyanya yang siap baca. ${ }^{7}$

Tulisan ini membahas tentang pengalaman batin sufistik Mustapa yang dituangkan dalam Naskah Mustapa yang belum pernah dipublikasikan, Asmarandana Ngagurit Kaburu Burit (Cod. Or. 7876). Berbagai narasi puitis seputar pengalaman batin sufistik dari pencarian hingga pencapaian diungkapkannya. Sebuah naskah yang menceritakan pengalaman pencarian diri secara eksklusif yang disebutnya sebagai sisa-sisa pengalaman (ruruntuk) suluk yang ditulis terlalu kesorean (ngagurit kaburu burit).

Identity: A Contribution of Haji Hasan Mustapa's Dangding", Al-Jamiah, vol. 50, no. 2, 2012.

'Lutfi Abas, "Prolegomena to Haji Hasan Mustapa's Mystical Cantos", Paper presented at a seminar in The Department of Malay Studies on October 6, 1976; Jajang Jahroni, "The Life and Mystical Thought of Haji Hasan Mustafa (1852-1930)", Thesis (Leiden University, 1999); Ahmad Gibson Al-Bustomi, "Eksistensi Manusia menurut K.H. Hasan Mustapa", Tesis (UIN Sunan Gunung Djati Bandung, 2009).

${ }^{7}$ Haji Hasan Mustapa, Dangding Djilid Anu Kaopat. Stensilan diusahakeun ku Ajip Rosidi (Bandung, Oktober 1960); Ajip Rosidi, Haji Hasan Mustapa jeung Karya-karyana (Bandung: Pustaka, 1989); Iskandarwassid, Ajip Rosidi, Josep CD., Naskah Karya Haji Hasan Mustapa (Bandung: Proyek Sundanologi, 1987). 


\section{Naskah Tasawuf di Tatar Sunda}

Tidak bisa dipungkiri bahwa jaringan Islam Nusantara yang berpusat di Haramayn terbangun sejak lama. ${ }^{8}$ Jaringan tersebut merangsang berkembangnya tradisi intelektual Islam Nusantara. Ditemukannya berbagai naskah keislaman Nusantara menunjukkan tradisi tersebut, meski seringkali dianggap sebagai pinggiran. Sebuah tradisi yang dianggap relatif mapan dengan adanya skriptorium dan aktifitas literasi sebagai media transmisi intelektual Islam. ${ }^{9}$

Di antara kategori naskah Nusantara, naskah keislaman (tasawuf), kiranya cukup banyak mendapat perhatian. Ia dianggap memiliki pengaruh besar dalam perkembangan bahasa dan sastra Nusantara. Sastra Melayu misalnya, harus mengakui kontribusi besar sastra sufistik dalam mengembangkan kesadaran dirinya. ${ }^{10}$ Braginsky menyebutkan bahwa justru karena pengaruh sastra sufistik ini, terbentuk kesadaran diri sastra Melayu klasik dengan ajarannya tentang yang indah, berfaedah dan kamal dalam karya sastra yang sejak akhir abad ke-16 hingga awal abad XIX merupakan cirinya yang penting. ${ }^{11}$ Namun, dibanding kajian naskah sufistik Melayu, ${ }^{12}$ perhatian terhadap naskah sufistik Sunda relatif masih ketinggalan. Padahal ia sangat signifikan dalam menunjukkan kuatnya arus Islamisasi di tatar Sunda yang terhubung dengan tradisi tasawuf Nusantara. Ia juga

${ }^{8}$ Azyumardi Azra, The Origins of Islamic Reformism in Southeast Asia: Networks of Malay-Indonesian and Middle Eastern 'Ulamä' in the Seventeenth and Eighteenth Centuries (Honolulu: ASAA-Allen \& Unwin and University of Hawai'i Press, 2004), 2.

'Oman Fathurahman, Tarekat Shattariyah di Minangkabau Jakarta: Prenada Media, EFEO, PPIM, KITLV, 2008), 17.

${ }^{10}$ Liaw Yock Fang, Sejarah Kesusasteraan Melayu Klasike (Jakarta: YOI, 1991), 380.

${ }^{11}$ V. I. Braginsky, Yang Indah, Berfaedah dan Kamal: Sejarah Sastra Melayu dalam Abad 7-19, terj. Hersri Setiawan (Jakarta: INIS, 1998), 435.

${ }^{12}$ Kajian mendalam sastra sufistik Melayu, terutama Hamzah Fansuri, misalnya dilakukan Syed Muhammad Naguib al-Attas, The Mysticism of Hamzah Fansuri (Kuala Lumpur: University of Malaya Press, 1970); V. I. Braginsky, "Some remarks on the structure of the Syair Perahu by Hamzah Fansuri", Bijdragen tot de Taal-, Land- en Volkenkunde 131 (1975), no. 4, Leiden, 407-26. 
menunjukkan bagaimana tradisi tasawuf diapresiasi ke dalam bentuk artikulasi Islam lokal.

Signifikansi lokalitas bisa dipahami karena tradisi tasawuf tidak sekedar bergelut dengan dunia keilmuan, tetapi juga membentuk model praktek sosial yang secara intensif berhubungan dengan tradisi lokal. Ini bisa dilihat dari perkembangan berbagai aliran tarekat yang berhasil memodifikasi dan mereformulasi posisinya di tengah masyarakat yang terus berubah. Christomy misalnya menunjukkannya pada naskah sufistik Martabat Tujub dan silsilah Syekh Abdul Muhyi (1640-1715) dalam tradisi tarekat Shattariyah di Pamijahan. ${ }^{13}$ Abdul Muhyi termasuk penyebar Islam di pedalaman selatan tatar Sunda. Ia pernah berguru tarekat kepada Abdurrauf al-Jawi di Aceh, lalu ke Baghdad, Mekah, dan Cirebon, kemudian menetap hingga wafat di Pamijahan. ${ }^{14}$ Artikulasi tasawuf lokal juga ditunjukkan Millie dalam tradisi manakiban di Pesantren Suryalaya dan tradisi Pangaosan Layang Seh di masyarakat Sunda, tempat karya sastra wawacan dibacakan. ${ }^{15}$ Naskah Wawacan Layang Seh merupakan teks sastra naratif tentang Syekh Abdul Qadir Jailani yang dibacakan dalam upacara siklus hidup orang Sunda (tali paranti). Ia merupakan teks berkarakter kultural dalam nuansa ritual lokal Sunda.

Tradisi tasawuf Sunda berkembang seiring dengan semakin kuatnya Islam di tatar Sunda pasca jatuhnya Kerajaan Sunda pada 1579. Cirebon dan Banten yang didukung Jawa-Mataram berhasil menanamkan pengaruh Islam dan budaya Jawa terhadap tradisi sastra Sunda. Dangding berada dalam pengaruh tersebut terutama sekitar abad XVII. Meski pun ia kemudian diserap secara kreatif sebagai ciri keterpelajaran orang Sunda. Sebagaimana Bujangga Manik, bangsawan Sunda yang berpetualang ke Jawa dan Bali, diceritakan dalam naskah abad

${ }^{13}$ Tommy Christomy, Signs of the Wali: Narratives at the Sacred Sites in Pamijahan, West Java (Canberra: ANU E Press, 2008), 91.

${ }^{14}$ Ibid., 39; Aliefya M. Santrie, "Martabat Alam Tujuh Karya Syaikh Abdul Muhyi", dalam Ahmad Rifa'i Hassan ed., Warisan Intelektual Islam Indonesia Telaah atas Karya-Karya Klasik (Bandung: Mizan, 1992), 111.

${ }^{15}$ Millie, Splashed the Saint..., 189-90. 
XVI, “bisa carék Jawa" (pandai berbahasa Jawa), ${ }^{16}$ maka dangding juga menunjukkan karakter tersebut dan menjadikannya sebagai salah satu kekayaan sastra dan budaya Sunda.

Dangding merupakan karya sastra tulis yang berisi berbagai hal, termasuk cerita (hikayat, roman) atau uraian agama dengan pola puisi 17 jenis pupuh. ${ }^{17}$ Seperti halnya macapat atau geguritan di Jawa, dangding biasa ditembangkan atau disenandungkan, bahkan pada acara yang dihadiri orang banyak (mamaos atau beluk), seperti melahirkan, mencukur bayi, dan lain-lain. ${ }^{18}$ Mengingat luasnya fungsi dangding, maka tidak heran bila beragam tema bisa ditemukan. Misalnya, pendidikan dan pengajaran (naskah Wulang Krama, Wulang Murid, Wulang Guru karya R. Haji Muhamad Musa dan Asmarandana Labir Batin karya R.A. Bratawidjaja); pengalaman batin (naskah Haji Hasan Mustapa); rasa kagum pada alam (Dangdanggula Laut Kidul karya Kalipah Apo), berbagai kejadian (Kiamat Leutik karya Tubagus Jayadilaga), kasih sayang antar manusia, tingkah laku manusia, kebudayaan ${ }^{19}$ hingga digunakan untuk surat-menyurat, ceramah dan wejangan yang dibacakan dalam tradisi pernikahan. ${ }^{20}$

Dari sekian banyak naskah Sunda, baik puisi maupun prosa, yang sudah diinventarisasi, ${ }^{21}$ naskah tasawuf Sunda umumnya

${ }^{16} \mathrm{~J}$. Noorduyn dan A. Teeuw, Tiga Pesona Sunda Kuna, terj. Hawe Setiawan (Jakarta: Pustaka Jaya, 2006).

${ }^{17}$ Ketujuh belas bentuk puisi pupuh tersebut adalah Asmarandana, Balakbak, Dangdanggula, Durma, Gambuh, Gurisa, Jurudemung, Kinanti, Ladrang, Lambang, Magatru, Maskumambang, Mijil, Pangkur, Pucung, Sinom, dan Wirangrong. Pupub inilah yang kemudian melahirkan karangan berbentuk wawacan dan guguritan. Pupub karenanya sangat terikat oleh nama, sifat (karakter), jumlah larik (padalisan) tiap bait (pada), jumlah suku kata (guru wilangan) pada tiap larik, bunyi vokal pada akhir tiap larik (guru lagu). Ma'mur Danasasmita, Wacana Bahasa dan Sastra Sunda Lama (Bandung: STSI Press, 2001), 171-2.

${ }^{18}$ Ajip Rosidi, Mencari Sosok Manusia Sunda (Bandung: Pustaka Jaya, 2010), 30-1, 194.

${ }^{19}$ Yus Rusyana dan Ami Raksanegara, Puisi Guguritan Sunda (Jakarta: Pusat Pembinaan dan Pengembangan Bahasa, Depdikbud, 1980), xvi.

${ }^{20}$ Ajip Rosidi, Guguritan (Bandung: Kiblat, 2011), 16.

${ }^{21}$ Edi S. Ekadjati \& Undang S. Darsa, Jawa Barat: Koleksi Lima Lembaga (Jakarta: Yayasan Obor Indonesia \& EFEO, 1999); Edi S. Ekadjati, Naskah Sunda (1988). 
berisi pembahasan tentang aspek imanensi dan transendensi realitas Tuhan yang berhubungan dengan upaya pensucian diri dalam menghayati hakekat Tuhan. ${ }^{22}$ Tema umum pensucian diri diungkapkan ke dalam bentuk narasi berupa tata aturan peribadatan, konsep teosofi tasawuf, pengalaman batin sufistik atau cerita simbolik. ${ }^{23}$

Naskah dangding Mustapa umumnya berisi pengalaman batin sufistik. Sebagiannya cenderung pada teosofi sufistik seperti puisi Wạ̣dah al-Wujüd dan prosanya tentang Martabat Tujuh. Sejumlah wawacan sufistik diketahui juga dinisbatkan kepada Mustapa, seperti Wawacan Prabu Dewi atau Prabu Rara (Hamzab) (Cod. Or. 7855). Naskah Asmarandana Ngagurit Kaburu Burit (Cod. Or. 7876), berkaitan dengan salah satu pengalaman batin sufistik Mustapa yang diungkapkan dengan bahasa puisi dangding sufistik Sunda.

\section{Sekilas Tentang Haji Hasan Mustapa}

Sejarah kehidupan Mustapa relatif jelas dan mudah diketahui. Hal ini disebabkan kesadarannya sendiri untuk menyelipkan berbagai cerita perjalanan hidupnya dalam karyakaryanya. Karya dangding pangkur Pangkurangna Nya Hidayat misalnya, menceritakan pengalamannya dengan Snouck Hurgronje (1857-1936):

Terus kikiyaian
Tujuh taun geus kitu indit deui
Disampeur ku Tuan Senuk
Bral atrok-atrokan
Ka Kajawan ka Ponorogo Madiun
Surakarta Adiningrat
Jogja Magelang basisir
Teu lila aya di imah
Balik deui nurutkeun pasti
Kumpeni
Diangkat jadi panghulu
Ka Aceh ka Sumatra

Terus kikiyaian

Tujub taun geus kitu indit deui

Disampeur ku Tuan Senuk

Bral atrok-atrokan

Ka Kajawan ka Ponorogo Madiun

Surakarta Adiningrat

Jogja Magelang basisir

Teu lila aya di imah

Balik deui nurutkeun pasti

Kumpeni

Ka Aceb ka Sumatra
Terus kyai-kyaian
Tujuh tahun setelah itu pergi lagi
Dijemput oleh Tuan Snouck
Pergi berkeliling jauh
Ke Jawa, ke Ponorogo, Madiun
Surakarta Adiningrat
Yogyakarta, Magelang, pesisir
Tidak lama ada di rumah
Pulang kembali mengikuti
Kompeni
Diangkat menjadi Penghulu
Ke Aceh, ke Sumatera 2008).

${ }^{22}$ Titus Burchart, Introduction to Sufi Doctrine (Indiana: World Wisdom,

${ }^{23}$ Kalsum, Wawacan Buana Wisesa Sebuah Karya Tasawuf: Edisi Teks dan Analisis Struktur (Bandung: Fakultas Sastra Unpad, 2008), 14. 
Hanteu lila dipindah deui ka

Bandung

Tab ieu loba saksina

Kawantu badag jasmani 24
Tidak lama dipindah lagi ke

Bandung

Ini banyak saksinya

Oleh karena besarnya badan

Kedekatan Mustapa dengan Snouck Hurgronje tidak dapat diabaikan karena sangat berpengaruh terhadap perjalanan hidupnya sebagai seorang elite pribumi. Kedudukan sebagai Penghulu Besar (boefd penghulu) di Aceh dan Bandung menjadikannya menjadi salah satu informan pribumi yang membuka informasi bagi Snouck untuk masuk ke sisi terdalam Islam dan Muslim di Hindia Belanda. ${ }^{25}$ Mustapa berasal dari keluarga camat perkebunan teh di Cikajang, Garut. Ia adalah model perpaduan antara pribadi santri dan ménak yang masuk ke dalam struktur kolonial. Ia adalah kelanjutan dari "Moesa" lain, dan Snouck adalah "Holle" lain. ${ }^{26}$ Ia menjadi elite penghulu Priangan sekaligus masuk ke dalam lingkaran kaum ménak dan pada gilirannya lingkaran kolonial. ${ }^{27}$ Kemampuan Mustapa dalam menguasai budaya Sunda menjadi alasan bagi Snouck untuk menariknya ke dalam birokrasi Belanda. Snouck sangat terobsesi deangan adat-recht (hukum adat) sehingga sangat beralasan menarik Mustapa sebagai informan kuncinya. Ini berbeda dengan ulama pesantren yang tetap menjadi kelompok independen dan berada di luar sistem kekuasaan kolonial. ${ }^{28}$

Mustapa lahir dari keluarga pesantren sekaligus akrab dengan tradisi budaya Sunda. Tidak sedikit dari keluarganya, terutama dari pihak ibunya yang menjadi ulama dan menjadi gurunya seperti K.H. Hasan Basri (Kiarakoneng, Garut) dan Kyai

${ }^{24}$ Haji Hasan Mustapa, Gendingan Dangding Sunda Birabi Katut Wirabmana Djilid A. (Bandung: Jajasan Kudjang, 1976), 49.

${ }^{25}$ Michael Francis Laffan, Islamic Nationhood and Colonial Indonesia, The Umma below the Winds (London-New York: Routledge Curzon, 2003), 82-4; Jajat Burhanudin, Ulama \& Kekuasaan: Pergumulan Elite Muslim dalam Sejarah Indonesia (Bandung: Mizan, 2012), 158.

${ }^{26}$ Tentang kedekatan Muhammad Moesa (1822-1886) dan K. F. Holle (1829-1896), lihat Mikihiro Moriyama, Semangat Baru: Kolonialisme, Budaya Cetak dan Kesastraan Sunda Abad ke-19, terj. Suryadi (Jakarta: KPG, 2005).

${ }^{27 N i n a ~ H . ~ L u b i s, ~ K e b i d u p a n ~ M e n a k ~ P r i a n g a n ~ 1800-1942 ~(B a n d u n g: ~ P u s a t ~}$ Informasi Kebudayaan Sunda, 1998).

${ }^{28}$ Burhanudin, Ulama \& Kekuasaan..., 168-72. 
Muhammad (Cibunut, Garut). Dari pihak ibunya pula banyak yang menjadi bujangga Sunda, panayagan dan pencipta lagu. ${ }^{29}$ Mustapa pernah pergi ke Mekah sebanyak tiga kali (1860-1862, 1869-1873, 1877-1882), menjadi kyai di Mesjid Agung Garut (1882-1887, 1889-1891), lalu ikut berkeliling Jawa mendampingi Snouck (1889), bertugas di Kutaraja Aceh (1892-1895), dan akhirnya menjadi Hoefd Penghulu Bandung (1895-1917). ${ }^{30}$ Bila merujuk pada rentang penulisan dangding yang cukup singkat (1900-1902), maka konsernnya pada tasawuf kiranya tidak jauh dari rentang waktu kehidupannya tersebut.

Dengan demikian, asumsi Abas, Atmakusumah dan Rosidi cukup beralasan tentang adanya pengaruh tradisi mistisisme Islam Nusantara setelah berkarir di Aceh (1892-1895). ${ }^{31}$ Ia dihubungkan dengan tradisi tarekat Syattariyah as-Sinkili, Abdul Muhyi dan al-Burhanfuri (w. 1620).32 Meskipun untuk interpretasi ajaran tasawufnya, Abas semata-mata menyandarkannya pada kajian Johns. ${ }^{33}$ Selain tradisi tasawuf Nusantara, kiranya tradisi sastra suluk Jawa boleh jadi mempengaruhinya terkait dengan kedudukannya sebagai elit pribumi dan perjalanannya mendampingi Snouck. ${ }^{34}$ Meski besar kemungkinan ia juga sudah mengetahui tradisi tasawuf seperti tampak pada karya Ibn 'Arabi, al-Jili, dan al-Burhanfuri selama

${ }^{29}$ Tini Kartni, et.al., Biografi dan Karya Pujangga Haji Hasan Mustapa (Jakarta: Pusat Pembinaan dan Pengembangan Bahasa Depdikbud Jakarta, 1985), 13.

30Jahroni, "The Life and Mystical..., 22, 41.

${ }^{31}$ Kartini, et. al., Biografi dan Karya..., 28; Ajip Rosidi, Manusia Sunda (Bandung: Kiblat Pustaka Utama, 2009), 153.

${ }^{32}$ Abas, "Prolegomena to Haji..., 35-6.

${ }^{33}$ A.H. Johns, The Gift Adressed to the Spirit of the Prophet (Canberra: The Australia National University, 1966).

${ }^{34}$ Catatan Snouck tentang perjalanannya itu, yang tebalnya 1337 halaman, kemudian diringkas PH. S. van Ronkel. "Aanteekeningen over Islam en Folklore in West-en Midden Java, Uit Het Reisjournaal van Dr. C. Snouck Hurgronje”, Bijdragen KITLV. 101 (1942): 311-39. Tentang sastra suluk Jawa, lihat P. J. Zoetmulder, Manunggaling Kawula Gusti, Pantheisme dan Monisme dalam Sastra Suluk Jawa, terj. Dick Hartoko (Jakarta: Gramedia, 1991); Simuh, Mistik Islam Kejawen Raden Ngabehi Ranggawarsita (Jakarta: UIPress, 1988); S. Soebardi, The Book of Cebolek (Leiden: KITLV-The HagueMartinus Nijhoof, 1975). 
dua belas tahun karirnya di Mekah sebagaimana diasumsikan Jahroni. ${ }^{35}$ Mustapa mengakui bahwa di sana ia pernah diajari kitab Tubfah (al-Mursalab ilā [Rüh] al-Nabiy) terutama oleh Shaykh 'Abdulhamid Dagastani atau Sarawani. ${ }^{36}$ Meskipun kiranya visi spiritual Mustapa jauh lebih penting dibanding sumber elemen formal yang mempengaruhi ekspresi tasawufnya.

\section{Tentang Naskah Asmarandana Ngagurit Kaburu Burit}

Naskah Ngagurit Kaburu Burit kemungkinan hanya terdapat di Universsiteitsbibliotheek (UB) Leiden. Naskah ini termasuk ke dalam Cod. Or. 7876. Berdasarkan catatan katalog Naskah Sunda, naskah ini beserta naskah-naskah Mustapa (Cod. Or. 7872-7879) lainnya diberi judul Kepercayaan dan Mistik atau dalam inventarisasi R.A. Kern ditandai dengan "over geloofsleer en mystiek" (bab kepercayaan dan mistik). ${ }^{37}$ Nama Mustapa sebagai pengarang naskah juga diketahui dari salah satu baitnya (2):

$\begin{array}{ll}\text { 2. Jalma sugriyaning jalma } & \text { Manusia setiap manusia } \\ \text { Jalma sugriya manusa } & \text { Manusia setiap manusia } \\ \text { Tamba kélangan jajatén } & \text { Supaya tidak kehilangan asal (jati) } \\ \text { Dikarang ku kaula } & \text { Dikarang oleh aku } \\ \text { Haji Hasan Mustapa } & \text { Haji Hasan Mustapa } \\ \text { Jadi hoefd panghulu Bandung } & \text { Jadi hoefd penghulu Bandung } \\ \text { Bayangan santri kobongan } & \text { Bayangan santri kobongan }\end{array}$

Nama "Hoefd Panghulu Bandung" pada bait tersebut merupakan jabatan yang diasosiasikan hanya untuk dirinya. Meski "Penghulu Bandung" tidak hanya Mustapa, tetapi nama ini seakan sudah identik dengan dirinya. Pencantuman nama tersebut umumnya biasa ditemukan pada karya-karya dangdingnya. Selain penghulu, Mustapa tetap tidak mengabaikan identitasnya yang tidak bisa lepas dari bayang-bayang santri yang diungkapkannya dengan kalimat bayangan santri kobongan. Kobong merujuk pada asrama sederhana tempat tinggal santri di pesantren Sunda. Sebuah ungkapan bahwa dirinya tidak pernah kehilangan kesadaran akan besarnya pengaruh tradisi pesantren dalam kehidupannya.

35Jahroni, "The Life and Mystical..., 24, 41.

${ }^{36}$ Rosidi, Haji Hasan..., 48.

${ }^{37}$ Ekadjati, Naskah Sunda..., 213. 
Naskah-naskah Mustapa yang ditemukan, baik puisi maupun prosa, umumnya adalah hasil salinan sekretarisnya, Wangsadihardja (Wangsadiredja), di Kantor Kepenghuluan Bandung. ${ }^{38}$ Hasil salinannya setelah mendapat persetujuan Mustapa, kemudian diserahkan kepada Snouck dan disimpan di Leiden sekitar 1936. Naskah Mustapa Cod. Or. 7876 kemungkinan adalah salinan Wangsadihardja yang disimpan di Leiden seperti tampak pada bagian dalam sampul "Legaat Prof. Dr. C. Snouck Hurgronje 1936”. Hasil penelusuran Rosidi di UB Leiden tahun 1984, umumnya fisik naskah asli karya Mustapa sudah sangat lapuk. Pembaca hanya diperkenankan melihat mikrofilmnya saja. ${ }^{39}$

Mustapa sebetulnya tidak memberikan judul pada hampir keseluruhan naskah dangding-nya. Ia hanya mencantumkan nama jenis pupuh-nya, asmarandana. Atas inisiatif Rosidi, judul naskah dibuat berdasarkan larik pertama di awal puisinya. Menurut Rosidi, naskah ini berjudul Asmarandana Ngagurit Kaburu Burit. ${ }^{40}$ Metrum Asmarandana (smara-dabana, asmara api) mengandung watak asmara dan cinta kasih. ${ }^{41}$ Menggambarkan puisi kerinduan Mustapa akan sentuhan Ilahi dalam perjalanan suluk-nya. Dalam pupub asmarandana, setiap bait terdiri dari 7 larik dengan urutan jumlah suku kata berikut: 8i-8a-8é/o-8a-7a-8u-8a.

Dalam naskah Cod. Or. 7876, terdapat empat naskah puisi dengan tiga metrum, yakni Asmarandana (Amit Nganggit Bismillabi dan Ngagurit Kaburu Burit), Sinom (Cat Mancat ka Balé Pulang) dan Dangdanggula berbahasa Jawa (Mila Ningsun Mider Deropati). Naskah Asmarandana Ngagurit Kaburu Burit diletakkan di urutan keempat (Cod. Or. 7876d). Rosidi sudah mentranskripsi dan mempublikasikan dua naskah puisi, yakni Asmarandana Amit Nganggit Bismillahi/Jajatén Tulén ${ }^{42}$ dan Dhangdhanggula Mila Ningsun

\footnotetext{
${ }^{38}$ Rosidi, Manusia Sunda..., 5.

${ }^{39}$ Ajip Rosidi, Ngalanglang Kesusastran Sunda (Jakarta: Pustaka Jaya, 1983), 74-87.

${ }^{40}$ Rosidi, Haji Hasan..., 496.

${ }^{41}$ Momon Wirakusumah dan Buldan Djajawiguna, Kandaga Tata Basa Sunda (Bandung: Ganaco, 1957), 47.

${ }^{42}$ Haji Hasan Mustapa, Dangding Djilid Anu Kaopat, stensilan diusahakeun ku Ajip Rosidi (Bandung: Oktober, 1960), 22-5.
} 
Mider Deropati. ${ }^{43}$ Tidak diketahui mengapa dua naskah lainnya tidak ikut dipublikasikan.

Naskah ini menggunakan bahasa Sunda beraksara pégon. Kertas yang digunakan kertas bergaris. Setiap halaman terdiri dari 23 baris. Jumlah halaman keseluruhan 13 halaman (recsoverto). Nomor halaman yang ditulis pada pojok kanan atau kiri atas naskah menunjukkan angka 26-38. Terdapat 123 bait puisi Asmarandana sebagaimana disebutkan dalam kolofon. Tidak dicantumkan tanggal penyalinan sebagaimana naskah dangding Mustapa lainnya. Tetapi dilihat dari urutan naskah sebelum dan sesudahnya, naskah ini ditulis sekitar Maret-April 1901. Dalam salah satu baitnya (27), Mustapa menyebut bahwa ia mengarang dangding ini di depan Gedung Tiara. Kemungkinan Mustapa menulis saat masih menjabat Hoefd Penghulu Bandung (18951917) dan tinggal di Jl. Balonggedé (Balonggedéweg) No. 5.44 Lokasi tersebut sekarang berada di sekitar Alun-alun.

27. Pepetikan kitab leutike

Walatra ka saréréa

Kanu naléngténg jajatén

Hareupeun Gedong Tiara

Nulisna asmarandana

Rahayu alam wạ̣dahu

Sorangan di pasamoan
Petikan dari Kitab Leutik

Bicara jujur pada semua orang

Pada siapapun yang bertanya kesejatian

Di depan Gedung Tiara

Menulis Asmarandana

Rahayu alam wạ̣dahu (tunggal)

Sendirian di tempat pertemuan

Selain koleksi UB Leiden, naskah salinan dangding Mustapa juga terdapat di Perpusnas Jakarta dan koleksi individu. Salah satunya adalah hasil salinan $M$. Wangsaatmadja, sekretaris Mustapa berikutnya. Hasil suntingannya itu diberi judul Adji Wiwitan I-IV.46 Sayangnya naskah aslinya kemudian dimusnahkan, setelah disalinnya ke aksara Latin. Hasilnya kemudian disusun ke dalam 4 Jilid. Jilid I dan IV sudah

${ }^{43}$ Rosidi, Haji Hasan ..., 477-92.

${ }^{44}$ Lihat surat berita wafatnya Mustapa yang dikirim E. Soeleiman (anak Mustapa) tiga hari setelah wafatnya Mustapa kepada Snouck tertanggal 23 Januari 1930 (Or. 8952 A 713) dalam https://socrates.leidenuniv.nl, diakses 8 April 2013.

${ }^{45}$ Kitab Leutik juga menjadi judul dangdingnya yang lain, Asmarandana Kami Boga Kitab Leutik (Kami Punya Kitab Kecil) (199 bait/pada). Mustapa, Dangding Djilid..., 39-47.

${ }^{46}$ Kartini, et.al., Biografi dan Karya..., 39. 
dipublikasikan ulang. ${ }^{47}$ Sayang Rosidi mencatat bahwa Jilid II tidak diketahui keberadaannya. Meski Ajip sempat mencatat judul-judulnya saja. Naskah Asmarandana Ngagurit Kaburu Burit tidak tercantum dalam daftar keempat koleksi tersebut. Ia menyebutkan bahwa naskah tersebut hanya terdapat di UB Leiden, dengan kode Cod. Or. 7876.48

Dari sekian naskah Mustapa yang sudah ditranskripsi dan dipublikasikan, naskah Asmarandana Ngagurit Kaburu Burit belum sama sekali. ${ }^{49}$ Salah satu alasannya kemungkinan karena materi naskah seputar ajaran tasawuf yang dipengaruhi wabdah al-wujud sehingga rentan kesalahpahaman, selain juga karena terdapat beberapa naskah yang tidak lengkap. ${ }^{50}$ Dibanding publikasi karya prosanya, dangding Mustapa cenderung didominasi renungan sufistik tentang pencariannya akan kesejatian diri yang dibungkus alam pikiran Sunda. Karenanya, naskah ini dan karya Mustapa lainnya tidak bisa dilepaskan dari konteks indigenisasi (mistisisme) Islam di tatar Sunda yang dalam bahasa Woodward semakin meneguhkan identitas Islam lokal yang jauh dari makna sinkretik, dikotomis, dan sekedar di permukaan sebagaimana diasumsikan Wessing, Geertz, dan Beatty. ${ }^{51}$

${ }^{47}$ Jilid I dimuat dalam Haji Hasan Mustapa, Gendingan Dangding Sunda Birahi Katut Wirahmana Djilid A (Bandung: Jajasan Kudjang, 1976), sedang Jilid IV dimuat dalam Haji Hasan Mustapa, Dangding Djilid Anu Kaopat, stensilan diusahakeun ku Ajip Rosidi (Bandung, Oktober 1960).

${ }^{48}$ Rosidi, Haji Hasan ..., 496.

${ }^{49}$ Haji Hasan Mustapa, Dangding Djilid Anu Kaopat (1960); Haji Hasan Mustapa, Gendingan Dangding Sunda Birabi Katut Wirahmana Djïlid A (1976); Haji Hasan Mustapa, Seri Guguritan Haji Hasan Mustapa (Asmarandana Nu Kami, Kinanti Kulu-kulu, Sinom Wawarian, Dangdanggula Sirna Rasa, Sinom Barangtaning Rasa) (Bandung: Kiblat, 2009); Ajip Rosidi, Haji Hasan Mustapa jeung Karya-karyana (1989); Iskandarwassid, Ajip Rosidi, Josep CD., Naskah Karya Haji Hasan Mustapa (1987); Yus Rusyana dan Ami Raksanagara, Puisi Guguritan Sunda, Jakarta: Pusat Pembinaan dan Pengembangan Bahasa Depdikbud, 1980); Edi S. Ekadjati, Empat Sastrawan Sunda Lama, (Jakarta: Depdikbud, 1994).

${ }^{50}$ Mustapa, Seri Guguritan..., 6.

${ }^{51}$ Mark R. Woodward, Islam in Java: Normative Piety and Mysticism in the Sultanate of Yogyakarta (Tucson: The University of Arizona Press, 1989); Robert Wessing, "Cosmology and Social Behavior in A West Javanese Settlement", Disertasi (The University of Illinois at Urbana-Champaign, 1974), 286; Clifford Geertz, The Religion of Java (Chicago: University of 


\section{Tasawuf Haji Hasan Mustapa dalam Naskah}

Meski dimensi sufistik tidak bisa sepenuhnya dilukiskan dengan persepsi apapun, tetapi ungkapan pengalaman batin sufistik kiranya bisa memberi gambaran esensi mistis yang terhubung dengan gejala mistik di semua agama. Schimmel membedakan gejala pengalaman para mistikus itu menjadi: mistik sebagai jalan, perubahan chemistri jiwa, dan kerinduan akan cinta. Semua sufi cenderung berada dalam salah satu dari ketiga citra mistik tersebut. Meski memiliki persamaan dan perbedaan, tetapi gejala tersebut berujung pada dua macam: mistik ketakterhinggan (mysticism of infinity) dan mistik kepribadian (mysticism of personality). ${ }^{52}$ Sosok Ibn 'Arabi, kiranya mewakili nuansa mistik pertama dan seringkali menjadi sasaran kritik para teolog dan ulama fiqih. Mustapa sebagaimana Ibn 'Arabi, kiranya berada dalam jalan sufistik yang tidak sekedar membentuk kepribadian Muslim Sunda yang saleh, tetapi secara mendalam menjangkau pengalaman batin sufistik yang berisi perenungan filosofis yang kuat dan pelik, yakni: 1) mencari kefanaan diri; 2) terselang menjadi manusia; 3) sapatemon pakula-kula; 4) Jatnika sebagai tujuan akhir, dan 5) ruruntuk suluk.

\section{Mencari Perasaan Kefanaan Diri}

Mustapa menggambarkan pengalaman sufistiknya tentang proses pencarian kesejatian atau yang ia sebut sebagai susulukan sisindiran itu dalam kerangka wabdah al-wujud. Menurutnya, pencarian itu pada dasarnya mencari "kefanaan diri" (nyiar fana) sampai sempurna. Ia mengikuti isyarat batin yang mengalir sampai di rasa, lalu seperti kata kyai dan santri: sabar dan tawakal (15-17).

15. Pangrasa ti barang lilir

Sugriya bangsaning jalma

Teu pilih agama naon

Leungit mukti, nyiar fana

Leungit Allah, nyiar betah
Perasaan dari sejak ingat

Tiap-tiap bangsa manusia

Tidak memilih agamanya apa

Hilang kecukupan, mencari kefanaan

Hilang Allah, mencari rasa betah

Chicago Press, 1976); Andrew Beatty, Varietes of Javanese Religion: An Anthropological Account (Cambridge: Cambridge University Press, 1999).

${ }^{52}$ Annemarie Schimmel, Mystical Dimention of Islam (Chapel Hill: The University of North Carolina Press, 1975), 5. 
Tepi katutug lagedu

Taya piubareunana

16. Piubareunana tadi

Diwarah rasa nyorangan

Kunaonna teu katembong

Jalan warta papaiyan

Nepi terusing rasa

Nepi ka nyurup ka bayu

Jatnika ludeunganana

17. Ludeunganana di nyaring

Geus cacap pasrab sumerah

Kana kersaning Yang Manon

Nu kasorang nu karasa

Sanalike harita

Nu kasebut ti lelembut

Kudu sabar tawekalan
Sampai selesai sempurna

Tiada lagi obatnya

Obatnya yang tadi

Dididik perasaan menyendiri

Sebabnya tidak tampak terlihat

Mengikuti alur kabar yang menyasar

Sampai terus ke rasa

Sampai seirama dengan angin/napas

Keberaniannya sejati

Beraninya saat bangun (sadar)

Setelah selesai, ia pasrah

Atas kehendak Yang Maha Melihat

Atas apa yang dilakukan, yang dirasa

Pada waktu itu juga

Yang disebut-sebut dari sejak kecil:

Harus sabar lagi tawekal

Dalam bait tersebut, Mustapa menggambarkan bahwa pengalaman siapapun yang sudah menyadari eksistensinya dari setiap agama akan berujung pada pencarian kefanaan diri. Ini mengingatkan akan salah satu tema besar tasawuf sebagai sebuah universalitas alam batin yang menghubungkan semua agamaagama. ${ }^{53}$ Bagi Mustapa, semua pengalaman keagamaan itu intinya adalah mencari kefanaan diri. Nama Tuhan tiada lagi ada, yang tersisa rasa nyaman dan betah dalam kesempurnaan.

Mustapa menggambarkan upaya penggapaian kesempurnaan itu tentu saja sangat tidak mudah. Upaya yang tak mudah itu dicapai melalui pembakaran profanitas diri. Mustapa menggunakan ungkapan nepi katutug legedu. Kata lagedu (kulit menghitam penuh kotoran) menggambarkan kerja keras dalam membakar profanitas diri sampai betul-betul selesai dan sempurna. Selesainya upaya itu ditandai dengan kulit yang menghitam penuh kotoran. ${ }^{54}$

${ }^{53}$ Geoffrey Parrinder, Mysticism in the World's Religions (Oxford: One World, 1995), 4, 185.

${ }^{54}$ Lagedoe, of look legedoe, ong. = belewoek, vuil, een korst op zich hebben, onder het vuil zitten (hetzij van het lichaam, hetzij van der kleeding), lihat S. Coolsma, Soendaneesch-Hollandsch Woordenboek (Leiden: A. W. Sijthoff's Uitgevers-Maatschappij, 1913), 317; Tutug... nepi ka tutugna n.k. anggeusna, n.k. antékna, cacap, lihat R.A. Danadibrata, Kamus Basa Sunda (Bandung: 
Untuk mencapai kesempurnaan tadi, Mustapa kemudian menyarankan agar mengikuti isyarat batin yang mengalir sampai di rasa, lalu seperti kata kyai dan santri: sabar dan tawakal. Isyarat batin dalam tradisi tasawuf ini berhubungan dengan jalan panjang dalam mendekatkan diri kepada Allah melalui sejumlah tahapan atau tingkatan yang dicapai seorang sälike (station, maqām, maqāmät) dan kondisi mental yang menyertainya (häl, aḅwāl). 55 Sebagaimana sufi besar seperti al-Kalabazi, al-Tusi, al-Ghazali, al-Qusyairi dan lainnya, Mustapa di sini menyebut tahap pencarian ini dengan maqam sabar dan tawakal. Keduanya merupakan bagian dari fase spiritualitas ke arah pencapaian puncak hakekat spiritual alam sejati (fanā fi al-haqq). ${ }^{56}$

Dalam konsep Ibn 'Arabi, suasana spiritual itu merupakan tahapan saat pancaran hati dihasilkan melalui tindakan timbalbalik antara sinaran ketuhanan dengan kesiapan hati itu sendiri (isti'dād). Stabil tidaknya maqām ini sangat ditentukan oleh kutub yang menentukan atau ditentukan. ${ }^{57}$ Ungkapan katutug lagedu dalam mencapai kejatnikaan kiranya merupakan gambaran yang sangat tepat dalam mengungkapkan akhir pencapaian spiritualitasnya, karena lahir dari apa yang dalam bahasa Corbyn disebut sebagai imajinasi kreatifnya sebagai mistikus Sunda. ${ }^{58}$

\section{Saat Terselang Menjadi Manusia}

Mustapa lalu menggambarkan bahwa kesejatian itu diraih setelah terselang menjadi manusia dan menunjukkan kemahakuasaan Tuhan. Kesejatian nanti juga terbuka dalam ketenangan hati, saat sendiri bukan karena saat dikagumi. Berlaku sopanlah pada orang lain, hiburlah dengan surga, takutilah dengan neraka. Tunjukkan dengan petunjuk Tuhan melalui hati, melalui rasa (bait 18-23).

Kiblat Buku Utama, 2007); Panitia Kamus LBSS, Kamus Umum Basa Sunda, (Bandung: Penerbit Tarate, 1985).

${ }^{55}$ Harun Nasution, Falsafat dan Mistisisme dalam Islam (Jakarta: Bulan Bintang, 1990), 63; Schimmel, Mystical Dimention..., 109.

${ }^{56}$ Reynold A. Nicholson, The Mystics of Islam (Indiana: World Wisdom, 2002), 21.

${ }^{57}$ Burckhardt, Introduction to Sufi..., 97.

${ }^{58}$ Henry Corbyn, Creative Imagination in Sufism of Ibn 'Arabi, Trans. Ralph Manheim (Princeton: Princeton University Press, 1969). 
18. Tawekalanana bukti

Hayang teu kudu ka sorang

Sihoréng papastén tulén

Kaselang jadi manusa

Nyataning purbawisésa

Pitutur timbul ti dapur

Dapurna jadi babasan

19. Babasan santri kyai

Kudu sabaran tawekal

Sesebréd nuju beberéd

Mun kasorang kari senang

Puguh éta nyaéta

Anu dipilurub sepuh

Susulukan sisindiran
Tawakalnya terbukti

Semula inginnya tidak usah tercapai

Ternyata takdirnya asli/murni

Terselang karena menjadi manusia

Menyatakan Yang Berkuasa

Nasehat datang dari sumbernya

Sumbernya jadi ungkapan

Ungkapan santri kyai

Harus sabar dan tawakal

Saling mengingatkan saat hampir selesai

Kalau selesai tinggal senang

Jelasnya itu tadi

Yang diikuti orang tua

Susulukan sisindiran

Dalam pandangan Mustapa, manusia berasal dari Tuhan. Karena berasal dari Tuhan Yang Suci, maka manusia pada dasarnya adalah suci. Potensi kesucian itu bergeser ketika manusia lahir ke dunia dan menyandang nama "manusia". Bentuk lahiriah dan nama (ngaran, panglandi) manusia itu seringkali menutupi dirinya dari Tuhan. Sebaliknya nama Tuhan di dunia yang dipersepsikan manusia juga kadang membuat manusia terhalang untuk mendekati-Nya. Karenanya upaya sufi adalah berusaha mencari eksistensi diri yang hakiki dan melewati batas-batas nama manusia tersebut.

Pentingnya manusia melewati batas 'manusia' itu, terkait dengan kedudukan manusia sebagai makhluk yang eksistensinya merupakan perwujudan Tuhan yang misteri dan tersembunyi. Manusia merupakan rahasia-Ku (al-insān sirri), demikian bunyi sebuah hadis populer di kalangan sufi. Diciptakannya manusia merupakan suatu cara Tuhan menunjukkan kemahakuasaan dan eksistensi-Nya. Karenanya menjadi manusia dalam bait tersebut berarti menyatakan kemahakuasaan-Nya (kaselang jadi manusa, nyataning purbawisésa).

\section{Puncaknya Sapatemon Pakula-kula}

Mustapa lalu menggambarkan proses pertemuan dengan kesejatian itu (pasamoan). Ia menyebutnya dengan sapatemon kawula pada kawula (pertemuan aku dengan aku), saling mengaku (pakula-kula). Ibarat tamu dengan tamu, sama-sama jatnika 
(mulia, utama) (bait 28). Jatnika itu sudah ada dari sejak eling, dididik Rasulullah untuk beribadah. Ia jadi bekal untuk berpetualang, saat 'melayang' menjalani kehidupan sesudah menjalankan syariat seperti salat, berbakti, berpuasa. Inilah perintah al-Qur'an dan Rasul yang menjadi mustika manusia agar setia pada tunggaling wujud, tunggaling rasa (29-31).

28. Pasamoan anu baketi

Pasamoan nu ngawula

Sapatemon sapatemon

Kawula pada kawula

Geusaning pakula-kula

Tatamu pada tatamu

Sasama urang jatnika

29. Jatnika ti barang éling

Pépéka di alam sangka

Mébméban kabawa paéb

Pangwarah ti Rasulullah

Rasana rasa sumembah

Puguh tutungguling maksud

Kalangkang bawaeun nyaba

30. Nyaba kamana ka mendi

Ngalayang entas sambéyang

Babalén entas babaktén

Dadaran entas puasa

Piwarangan sorangan

Tutunggul paréntah rosul59

Ngedalkeun parentah Qur'an

31. Qur'anul adhimi nu tadi60

Pipokeunana sorangan

Maréndé mépéndé saré

Saréréa gé harayang

Mustikaning manusa

$\mathrm{Nu}$ tubu tunggaling wujud

$W$ alatra tunggaling rasa
Pertemuan yang berbakti

Pertemuan yang mengabdi

Bertemu terus bertemu

Kawula dengan kawula

Saling menganggap kawula pada kawula

Tamu dengan tamu

Sama-sama mulia

Mulia dari sejak eling

Rewel di alam penuh sangka

Hampir saja terbawa mati

Didikan dari Rasulullah

Rasanya rasa menyembah

Ternyata penanda maksud

Bayangan tuk bepergian

Bepergian kemana saja

Melayang sesudah shalat

Berulang-ulang sesudah berbakti

Memberi penjelasan sesudah puasa

Disuruh oleh sendiri

Penanda perintah Rasul

Menyampaikan perintah Qur'an

Qur'anul adhimi yang tadi

Disampaikan sendiri

Menemani tidur agar tenang

Semua orang juga ingin

Permatanya manusia

Yang setia pada tunggaling wujud

Jelas-jelas tunggaling rasa

Pasamoan atau sapatemon merupakan puncak pencarian eksistensi diri (tunggaling wujud, tunggaling rasa) yang berujung pada

${ }^{59}$ Tutunggul asalnya berarti nisan penanda kuburan.

${ }^{60}$ Mustapa seringkali menyebut Qur'anul Adbimi. Ia juga kemudian menulis prosa tafsir Al-Qur'an berjudul Qur'anul Adbimi, Adji Winitan Kitab Sutji, Kenging ngumpulkeun Wangsaatmadja, stensilan t.th. 
pencapaian kesejatian diri yang tidak berjarak lagi. Mustapa kiranya membedakan diri dan Tuhan dalam konteks waḅdah alwujūd, yakni sebagai gambaran pertemuan aspek manusia (nasüt) dan aspek ketuhanan (labüt) dalam dirinya. Jarak keduanya dianggap tak terbatas. Suluk merupakan sebuah perjalanan dari nasùt ke labüt. Dirinya (yang terselang) menjadi manusia disadari berasal dari Tuhan dan harus kembali ke Tuhan. Ia harus mengalami penyatuan eksistensi kembali (waḅdab al-wujūd) sehingga mampu memancarkan mutiara eksistensi-Nya yang tersembunyi di dunia (kanzan makhfiyyan), menunjukkan kebesaran-Nya, dan mengemban sifat-sifat Ilahi. Kehendaknya harus menyatu dengan kehendak Tuhan. Inilah pencarian labüt dalam nasüt. Layaknya logika paradoksal antara bentuk (form) dan isi (essence). Pada aspek ketuhanan terdapat aspek manusia, dan demikian pula sebaliknya. ${ }^{61}$ Baginya ketika ekstase terjadi tidak pernah sampai kehilangan aspek manusia atau pun kehilangan aspek ketuhanan. Tidak ada yang lenyap, masih manusia dan masih Tuhan. Penyatuan eksistensial inilah yang seringkali disalahpahami oleh para ulama (zahir) dengan menuding secara panteistik bahwa ia betul-betul melebur dan lenyap.

Gambaran peleburan eksistensi diri ini juga kiranya tepat untuk memahami puisi Mustapa lainnya yang sangat populer terutama di kalangan pengagumnya. Dalam Kinanti Puyuh Ngungkung dina Kurung, ia menggambarkannya dengan perasaan hilangnya objek, yang ditemukan hanya aku sang ego (aing) yang sudah tiada lagi jarak, bukan lagi hamba ('abd).

\section{Ngalantung neangan tangtung Aing deui aing deui \\ Sapanjang neangan saba \\ Aing deui aing deui \\ Sapanjang neangan beja \\ Yakin deui yakin deui ${ }^{62}$}

\begin{abstract}
Mencari-cari pijakan eksistensi Aku lagi Aku lagi

Sepanjang pencarian siapa Aku lagi Aku lagi

Sepanjang mencari kabar berita Yakin lagi yakin lagi
\end{abstract}

Dengan demikian, dalam tahap pencapaian ini, Mustapa kiranya tidak bisa dikatakan jatuh pada ajaran panteisme heterodoks sebagaimana disangkakan banyak orang. Sebuah ajaran tasawuf yang meyakini bahwa hanya ada satu wujud

\footnotetext{
${ }^{61}$ Jahroni, "The Life and Mystical..., 62-3.

62Mustapa, Gendingan Dangding..., 140; Rosidi, Haji Hasan..., 96.
} 
semata, yakni Wujud Allah, sedang selain-Nya hanyalah ilusi. ${ }^{63}$ Mustapa tidak meyakini bahwa realitas ini tiada, tidak juga abadi dan berada pada Tuhan, tetapi menganggap bahwa ia tidak bisa dipisahkan dari Tuhan dan sangat bergantung pada-Nya. Karenanya, kita tidak sepenuhnya bisa mengatakan bahwa Mustapa meyakini ajaran waḅdah al-wujūd secara ekstrem. Di banding sufi Sunni lainnya, tasawuf Mustapa kiranya menekankan pada misteri ketersembunyian Tuhan yang hanya bisa diketahui melalui ciptaan-Nya. Ini misalnya terjadi juga pada tasawuf Hamzah Fansuri. ${ }^{64}$ Karenanya dalam banyak dangdingnya Mustapa menggunakan ragam simbol dan metafor yang tetap membedakan antara dirinya dengan Tuhan meski tidak terpisahkan, antara aren dengan caruluk, iwung dan bambu, bambu-haur, bambu-angklung, duwegan-kitri, beras-padi, sirungbenih, tongtolang dengan nangka, hayam dan endog (ayam dan telur) dan yang lainnya.

Pembedaan Khalik-makhluk menjadi ciri dari upaya tafsir ulama Nusantara atas ajaran wahdah al-wujüd. Umumnya ulama sufi Nusantara cenderung mengajukan upaya rekonsiliasi tasawuf (neo-sufisme). Mustapa kiranya juga sangat dipengaruhi tema besar tasawuf abad ke-17 dan 18 ini. Sehingga bisa dipahami bila Mustapa pada bait di atas juga cenderung menekankan pada tasawuf yang tidak mengabaikan syariat (sambeang, puasa).

\section{Pencarian di Masa Tua dan Ruruntuk Suluk}

Dalam bait selanjutnya, Mustapa menyadari bahwa ia belajar mencari kebahagiaan batin (susulukan) saat usia sudah tua (tengah tuwub), sudah kaya dengan dunia, saat sudah tenang mencari nafkah (pangupajiwa). Saatnya ia mendidik diri sendiri, merasa yang tidak terasa oleh orang lain. Saatnya ia membalik kesadaran, rasa terbalik rasa, rasa yang mulus rahayu (48-50). Inilah pusaka diri yang hilang sedari muda, baru ketemu sekarang (83).

${ }^{63} \mathrm{Abu}$ al-Wafa' al-Ganimi al-Taftazani, Sufi dari Zaman ke Zaman, terj. Ahmad Rofi' 'Utsmani (Bandung: Pustaka, 1987), 200.

${ }^{64}$ Karel Steenbrink, "Qur'an Interpretations of Hamzah Fansuri (CA. 1600) and Hamka (1908-1982): A Comparison", Studia Islamika, vol. 2, no. 2 , $1995,84$. 
Ruruntuk suluk (sisa suluk) saat lewat masanya, hasil berdoa saat kecil, hasil mencari dari muda (87).

48 Kalangkang ati keur leutik. Babanda kaliwat mangsa

Pangajén taya nya ajén Geus wayah datang hidayah Cacap pangupajiwa Lampahna geus tengah tuwuh Murak bagjaning sorangan

49 Sorangan malikekeun diri Geus cacap nanya ka saha Tadi gé ngawarah manéh Mirasa nu teu Karasa

Rasa tara sarasa

Rasa batur rasa batur Sorangan rasa sorangan

50 Ka sorangan malikekeun ati Mamaca nu beunang ngala Kitu kénéb kitu kénéh Sakecap tibalik rasa Rasa tibalik rasa Rasa nu mulus rahayu Taya oméaneunana

83 Sirna bagjaning pirbadi Murak pusaka sorangan $\mathrm{Nu}$ leungit ti babaréto $\mathrm{Nu}$ kélangan ti ngongora Timu-timu ayeuna Geus lusub ku pangaweruh Geus cacap nyiar jatnika ...

86 Bobojodanana lilir

Genah ku bagjaning awak Bojod-bojod geus karolot Taya pisukaeunana Ngawula kumawula

Ruruntuk suluk geus dumuk Jatnika liwat ti mangsa
Bayangan hati ketika kecil

Mencari harta benda sudah lewat masanya Mencari penghargaan, tidak ada yang mau Ketika sudah datang waktunya hidayah Sempurnanya nafkah

Amalnya sudah tengah tuwuh

Membuka kebahagiaan sendiri

Sendiri membalikkan kesadaran

Sudah waktunya bertanya pada siapa

Tadi juga mendidik diri sendiri

Merasakan yang tidak terasa

Rasa yang tidak seperasaan

Masing-masing, itu perasaan orang lain

Ini perasaan diri sendiri

Pada diri sendiri membalikkan hati

Membaca yang diperoleh

Ternyata begitu-begitu saja

Satu kata rasa terbalik

Rasa berbalik rasa

Rasa yang mulus rahayu

Tiada kekurangannya

Sirna, kebahagiaan pribadi

Membuka pusaka sendiri

Yang hilang dari sejak dahulu

Yang kehilangan dari sejak muda

Ketemu-ketemu sekarang

Sudah lusuh oleh ilmu

Sudah waktunya mencari kemulyaan

Kerusakannya tampak

Nikmat karena bahagia badan

Rusaknya ketika sudah tua

Tiada kesenangannya lagi

Mengabdi lagi taat

Sudah jelas sisa-sisa suluk

Kemuliaan lewat masanya

Ruruntuk semula berarti barang atau peralatan yang sudah rusak dan tidak terpakai meski ada yang masih bisa digunakan. Istilah ini digunakan Mustapa untuk menggambarkan 
pengalaman sufistiknya yang dirasa sudah terlalu tua meski belum terlalu terlambat sehingga masih bisa dijadikan bahan renungan batin. ${ }^{65}$ Dalam tradisi tarekat, mempelajari hakekat diri dengan menempuh jalan suluk umumnya dilakukan oleh mereka yang sudah tua. Mereka mengamalkan zikir dan wirid saat usia sudah lanjut usia, yang tidak lagi didorong oleh kehidupan duniawi untuk memperoleh kebahagiaan. Mereka yang telah menyadari bahwa akhir hidupnya dirasakannya sudah dekat, sehingga kebutuhan spiritual untuk lebih mendekati Tuhan menjadi tuntutan yang sangat penting. 66 Mustapa kiranya merasakan hal yang sama, saat usia sudah tengah tuwub (50-60 tahun), saat mencari harta bukan lagi masanya, ia merasakan perlunya membuka kebahagiaan sejati melalui jalan suluk sebelum terlambat. Keterlambatan saat usia dan waktu yang tidak lagi tepat. Dalam puisinya yang lain, Kinanti Ngaburun Balung, Mustapa misalnya menggambarkan keterlambatan dalam mencari jalan kesejatian diri itu dengan ungkapan kaporotan ganti ngaran, duwegan santri teu amis (terlambat keburu berganti nama, ibarat dewegan santri yang sudah tidak lagi manis).

39. Mun disuguh angeun iwung

Ulah menta angeun awi

Najan enya kitu té mah

Katelahna kebon awi

Lalandian sababatan

Awi deui awi deui

40. Na saha nu ngebon sintung

Ngan aya nu melak kitri

Duwegan gé saliwatan

Geuwat bisi kolot teuing

Kaporotan ganti ngaran

Duwegan santri teu amis
Kalau disuguhi sayur imung

Jangan meminta sayur bambu

Meski begitu juga

Disebutnya kebun bambu

Sebutan keumuman

Bambu lagi bambu lagi

Siapa yang berkebun sintung

Cuma ada yang menanam kitri

Duwegan juga cuma sebentar saja

Cepatlah nanti keburu tua

Ketika tidak keburu nanti berubah nama

Menjadi duwegan santri yang tidak manis

Mustapa dalam bait tersebut bermain metafor iwnng (anak bambu), awi (bambu), sintung (pelepah yang menutup bunga kelapa), kitri (benih pohon kelapa) dan dewegan. Sebagaimana

${ }^{65}$ Ruruntuk, any spoiled worn-out implement or thing. So much spoiled as to be hardly useable. Lihat Jonathan Rigg, A Dictionary of the Sunda Language of Java (Batavia: Lange \& Co., 1862), 410.

${ }^{66}$ Zamakhsyari Dhofier, Tradisi Pesantren (Jakarta: LP3ES, 1981), 150. 
banyak metafor alam kesundaan lainnya, semua menggambarkan hubungan khalik-makhluk dalam proses pencarian diri. Mustapa menggunakan metafor alam kesundaan yang dijejakkan dalam bingkai tradisi sufistik. ${ }^{67}$ Iwung dan sintung sebagai metafor diri, sedang awi dan kitri sebagai metafor hakekat Tuhan sejati. Dewegan digunakan sebagai gambaran saat yang tepat dalam mencari hakekat diri, jangan sampai terlambat (kaporotan) karena hanya sebentar. Ibarat dewegan yang bisa dinikmati hanya saat usia kelapa yang tepat dan sebentar sebelum berubah menjadi dewegan santri (dewegan tanggung karena airnya tidak lagi manis dan sudah terdapat daging kelapa yang tebal di dalamnya). Karenanya sebagaimana tradisi tarekat, jalan suluk ditempuh Mustapa saat tiba masa yang tepat. Saat usia yang sangat matang (lebih 50 tahun) dengan kehidupan dunia yang sudah mapan sebagai penghulu Bandung hingga pensiun. Ini semua adalah hasil didikan selama di pesantren dahulu yang ia rasakan pada saatnya yang tepat. Saat ia kemudian merasakan kebahagiaan yang selama ini ia cita-citakan dalam menempuh rasa jatnika (bagja nu tadi dibaring, pon nyorang rasa jatnika) (bait 118).

\section{Catatan Akhir}

Naskah dangding sufistik Mustapa menunjukkan secara jelas kreativitas lokal dalam merespons tradisi intelektual tasawuf filosofis. Kajian ini signifikan dalam menunjukkan kreativitas lokal tasawuf Sunda dalam menyerap pengaruh tasawuf wahdah al-wujud yang diekspresikan dengan bahasa sastra dan alam Sunda. Melalui karyanya, ia mengungkapkan pengalaman sufistik melalui karakteristik alam kesundaan. Bujangga Sunda terbesar ini karenanya memiliki kontribusi penting dalam proses indigenisasi Islam di tatar Sunda. Di tangannya, tampak harmonisasi ajaran Islam dengan alam pikiran Sunda. Hasil pembacaan menunjukkan bahwa naskah ini berisi ungkapan perjalanan sufistik (susulukan). Dari tahap pencarian kefanaan diri saat terselang menjadi manusia hingga mengalami pertemuan (sapatemon). Puncaknya ia mengalami perasaan membaurnya eksistensi diri. Tidak ada lagi objek, semua subjek (pakula-kula).

${ }^{67}$ Rohmana, "Sundanese Sufi..., 317. 
Inilah kesejatian yang sebenarnya (jajaten tulen) di alam jatnika. Dengan merendah Mustapa menyebut puisi tasawufnya ini dengan ruruntuk suluk (rongsokan suluk) yang ditulis terlalu kesorean (ngagurit kaburu burit). Meski dalam kajian tasawuf, tidak mudah pengalaman batin itu untuk dikaji, karena kata-kata tidak akan bisa mengukur kedalamannya. Namun, analisis tasawuf terhadap puisi sufistik Mustapa kiranya bisa menunjukkan sedikit gambaran perjalanan pengalaman sufistik yang dirasakannya. $W a$ al-Läh a lam bi al-sawāh.

\section{Daftar Pustaka}

Abas, Lutfi. 1976. "Prolegomena to Haji Hasan Mustapa's Mystical Cantos". Paper presented at a seminar in The Department of Malay Studies on October 6, 1976.

Al-Attas, Syed Muhammad Naguib. 1970. The Mysticism of Hamzah Fansuri. Kuala Lumpur: University of Malaya Press.

Azra, Azyumardi. 2004. The Origins of Islamic Reformism in Southeast Asia: Networks of Malay-Indonesian and Middle Eastern 'Ulamä' in the seventeenth and eighteenth centuries. Honolulu: ASAA-Allen \& Unwin and University of Hawai'i Press.

Beatty, Andrew. 1999. Varietes of Javanese Religion: An Anthropological Account. Cambridge: Cambridge University Press.

Braginsky, V. I. 1998. Yang Indah, Berfaedah dan Kamal: Sejarah Sastra Melayu dalam Abad 7-19, terj. Hersri Setiawan. Jakarta: INIS.

. 1975. "Some remarks on the structure of the Syair Perahu by Hamzah Fansuri”. Bijdragen tot de Taal-, Landen Volkenkunde 131.4.

Burckhardt, Titus. 2008. Introduction to Sufi Doctrine. Indiana: World Wisdom.

Burhanudin, Jajat. 2012. Ulama \& Kekuasaan: Pergumulan Elite Muslim dalam Sejarah Indonesia. Bandung: Mizan.

Al-Bustomi, Ahmad Gibson. 2009. Eksistensi Manusia menurut K.H. Hasan Mustapa, Tesis, UIN Sunan Gunung Djati Bandung. 
Christomy, Tommy. 2008. Signs of the Wali: Narratives at the Sacred Sites in Pamijahan, West Java. Canberra: ANU E Press.

Coolsma, S. 1913. Soendaneesch-Hollandsch Woordenboek. Leiden: A. W. Sijthoff's Uitgevers-Maatschappij.

Corbyn, Henry. 1969. Creative Imagination in Sufism of Ibn 'Arabi. Trans. Ralph Manheim. Princeton: Princeton University Press.

Danadibrata, R.A. 2007. Kamus Basa Sunda. Bandung: Kiblat Buku Utama.

Danasasmita, Ma'mur. 2001. Wacana Bahasa dan Sastra Sunda Lama. Bandung: STSI Press.

Dhofier, Zamakhsyari. 1981. Tradisi Pesantren. Jakarta: LP3ES.

Ekadjati, Edi S. 1988. Naskah Sunda: Inventarisasi dan Pencatatan. Bandung: Lembaga Penelitian Unpad-The Toyota Foundation.

Depdikbud.

1994. Empat Sastrawan Sunda Lama. Jakarta:

Ekadjati, Edi S., \& Undang S. Darsa, 1999. Jawa Barat: Koleksi Lima Lembaga. Jakarta: Yayasan Obor Indonesia \& EFEO.

Fathurahman, Oman. 2012. Ithäf al-Dhaki, Tafsir Waḅdatul Wujud bagi Muslim Nusantara. Bandung: Mizan-EFEO. . 2008. Tarekat Syattariyah di Minangkabau. Jakarta:

Prenada Media, EFEO, PPIM, KITLV.

Geertz, Clifford. 1976. The Religion of Java. Chicago: University of Chicago Press.

Iskandarwassid, Ajip Rosidi, Josep CD. 1987. Naskah Karya Haji Hasan Mustapa. Bandung: Proyek Sundanologi.

Jahroni, Jajang. 1999. "The Life and Mystical Thought of Haji Hasan Mustafa (1852-1930)". Thesis Leiden University.

Johns, A.H. 1961. "Sufism as a Category in Indonesian Literature and History", Journal of Southeast Asian History, vol. 2, no. 2, Indonesia (1961). 1966. The Gift Adressed to the Spirit of the Prophet.

Canberra: The Australia National University.

Kalsum. 2008. Wawacan Buana Wisesa Sebuah Karya Tasawuf: Edisi Teks dan Analisis Struktur. Bandung: Fakultas Sastra Unpad. 
Kartini, Tini., et. al. 1985. Biografi dan Karya Pujangga Haji Hasan Mustapa. Jakarta: Pusat Pembinaan dan Pengembangan Bahasa Depdikbud Jakarta.

Laffan, Michael Francis. 2003. Islamic Nationhood and Colonial Indonesia, The Umma below the Winds. London-New York: Routledge Curzon.

Lubis, Nina H. 1998. Kebidupan Menak Priangan 1800-1942. Bandung: Pusat Informasi Kebudayaan Sunda.

Millie, Julian Patrick. 2006. "Splashed by the Saint: Ritual Reading and Islamic Sanctity in West Java". Diss. Leiden University.

Moriyama, Mikihiro. 2005. Semangat Baru: Kolonialisme, Budaya Cetak dan Kesastraan Sunda Abad ke-19, terj. Suryadi. Jakarta: KPG.

Mustapa, Haji Hasan. 1960. Dangding Djilid Anu Kaopat. Stensilan diusahakeun ku Ajip Rosidi. Bandung. - 1976. Gendingan Dangding Sunda Birahi Katut Wirahmana Djilid A. Bandung: Jajasan Kudjang. 2009. Seri Guguritan Haji Hasan Mustapa (Asmarandana $\mathrm{Nu}$ Kami, Kinanti Kulu-kulu, Sinom Wawarian, Dangdanggula Sirna Rasa, Sinom Barangtaning Rasa). Bandung: Kiblat.

. T.th. Qur'anul 'Adhimi Adji Wiwitan Petikan Ajat Kur'an Sutji, Kenging ngumpulkeun Wangsaatmadja, stensilan.

Nasution, Harun. 1990. Falsafat dan Mistisisme dalam Islam. Jakarta: Bulan Bintang.

Nicholson, Reynold A. 2002. The Mystics of Islam. Indiana: World Wisdom.

Noorduyn, J., dan A. Teeuw, 2006. Tiga Pesona Sunda Kuna, terj. Hawe Setiawan. Jakarta: Pustaka Jaya.

Or. 8952 A 713 dalam https://socrates.leidenuniv.nl, diakses 8 April 2013.

Panitia Kamus LBSS. 1985. Kamus Umum Basa Sunda. Bandung: Penerbit Tarate.

Parrinder, Geoffrey. 1995. Mysticism in the World's Religions. Oxford: One World. 
Rigg, Jonathan. 1862. A Dictionary of the Sunda Language of Java. Batavia: Lange \& Co.

Rohmana, Jajang A. 2002. "Sundanese Sufi Literature and Local Islamic Identity: A Contribution of Haji Hasan Mustapa's Dangding", Al-Jamiah, vol. 50, no. 2, 2012.

Rosidi, Ajip. Ngalanglang Kesusastran Sunda. 1983. Jakarta: Pustaka Jaya.

Bandung: Pustaka.

. 1989. Haji Hasan Mustapa jeung Karya-karyana. . 2009. Manusia Sunda, Bandung: Kiblat Pustaka

Utama. . 2010. Mencari Sosok Manusia Sunda. Bandung: Pustaka Jaya. . 2011. Guguritan. Bandung: Kiblat.

Rusyana, Yus., dan Ami Raksanegara. 1980. Puisi Guguritan Sunda. Jakarta: Pusat Pembinaan dan Pengembangan Bahasa, Depdikbud.

Santrie, Aliefya M. 1992. "Martabat Alam Tujuh Karya Syaikh Abdul Muhyi". Warisan Intelektual Islam Indonesia Telaah atas Karya-Karya Klasik. dd. Ahmad Rifa'i Hassan. Bandung: Mizan.

Schimmel, Annemarie. 1975. Mystical Dimention of Islam. Chapel Hill: The University of North Carolina Press.

Simuh. 1988. Mistik Islam Kejawen Raden Ngabebi Ranggawarsita. Jakarta: UI-Press.

Soebardi, S. 1975. The Book of Cebolek. Leiden: KITLV-The Hague-Martinus Nijhoof.

Steenbrink, Karel. 1995. "Qur'an Interpretations of Hamzah Fansuri (CA. 1600) and Hamka (1908-1982): A Comparison", Studia Islamika, vol. 2, no. 2, 1995.

Al-Taftazani, Abu al-Wafa' al-Ghanimi. 1987. Sufi dari Zaman ke Zaman, terj. Ahmad Rofi' 'Utsmani. Bandung: Pustaka.

van Bruinessen, Martin. 1994. "The Origins and development of Sufi orders (tarekat) in Southeast Asia, Studia Islamika, vol.1, no. 1, 1994.

van Ronkel, PH. S. 1942. "Aanteekeningen over Islam en Folklore in West-en Midden Java, Uit Het Reisjournaal van 
Dr. C. Snouck Hurgronje”, Bijdragen KITLV. 101 (1942): 311-339.

Wessing, Robert. 1974. "Cosmology and Social Behavior in A West Javanese Settlement". Diss. the University of Illinois at Urbana-Champaign.

Wirakusumah, Momon. dan Buldan Djajawiguna. 1957. Kandaga Tata Basa Sunda. Bandung: Ganaco.

Woodward, Mark R. 1989. Islam in Java: Normative Piety and Mysticism in the Sultanate of Yogyakarta. Tucson: The University of Arizona Press.

Yock Fang, Liaw. 1991. Sejarah Kesusasteraan Melayu Klasik. Jakarta: YOI.

Zoetmulder, P. J. 1991. Manunggaling Kawula Gusti, Pantheisme dan Monisme dalam Sastra Suluk Jawa, ter. Dick Hartoko. Jakarta: Gramedia, 1991. 